\title{
Parents' Financing at Master Level in Semester System of Tribhuvan University
}

\author{
Min Raj Poudel \\ minrajpaudel19@gmail.com \\ Lecturer \\ Central Department of Education, T.U., Kirtipur
}

\begin{abstract}
Parents' financing of education has been a major challenge and a policy issue to be settled in each country appropriately. This financing is defined as the direct private non-institutional cost to the students that occurs as a result of rent, uniform, coaching, transportation fare etc. To carry out this study post-positivism paradigm and survey design was followed being it quantitative research. The objective of the study was to analyze the direct private non-institutional financing of education at a master level under the semester system in TU. A total of 120 students from the six Central Departments of University Campus, Kirtipur were selected randomly for the study. Based on results and discussion, it is concluded that to live in Kathmandu as a student of University Campus of Tribhuvan University, annually each student should manage the direct private noninstitutional costs by NRS 1,17,615.00 (\$999.73), NRS 1,45,945.80 (\$1,240.54), NRS 1,41,685.60 (\$1,204.33), NRS 1,54,384.35 (\$1,312.27), NRS 1,99,841.90 (\$1,698.66), NRS 1,66,590.00 (\$1,416.02), and NRS 9,26,062.65 (\$7,871.53) to get the master degree from the Central Department of Education, Nepali, English, Management, Zoology and Chemistry respectively. In addition, the students should spend NRS 56,268.77 (\$478.28) annually in rent which is the higher by 36.46 percent over the total expenditure. Likewise, the female students have to spent by NRS 1,69,993.44 (\$1,444.94) and the male students by NRS 1,38,693.84 (\$1,178.9), however, the female students' funding was higher by NRS $31,299.60$ (\$266.05) or 22.57 percent than their male counterpart.
\end{abstract}

Keywords: Parents' financing - non-institutional - higher education - semester system -Tribhuvan University

\section{Introduction}

The policy making aspect of education plays an important role in one aspect of funding for public and private sector education as it describes how education is provided to the people and what it costs (Chattopadhyay, 2007). In terms of economics, financing is related to the investment. There areboth the private and the social investment in education which contributes to economic development and raises the income of the poor as much as investment in physical capital does (Akpotu, 2008).Likewise, educational financing is treated as the cost of education refers to the amount of money spent to acquire or impart education (Aghenta, 1993). It is a measure of what a 
student has to give up in order educating an individual or a group of people. It refers to the amount spent on education by the individual students' parents during the academic year (Khandagale \& Pandya, 2014). It is incurred by producers (educational institutions) or consumers (students and their parents) (Obradovic, 2008). The financing education explores both the investments and returns to education and human capital (UNESCO \& OECD, 2002). Therefore, students or parents seem to be ready to invest time and money in education (Lugaz \& Grauwe, 2016).

Parents' financing on education is defined as the direct private non-institutional costs and investment that are made either by the students or their parents or both. The parents' financing on education can be divided into direct and indirect (Jamison, 2009). Likewise, direct parents' financing (DPF) on education can also be categorized into institutional and non-institutional. The DPF relates to the total expenditure incurred by the households towards the education of their children (Lugaz \& Grauwe, 2016). It includes the expenditure directly related to instruction like fees, fines and other charges that have to pay in the account of educational institution, that are called the direct parents' institutional costs (DPIC), and non-fee components of education like price of learning materials, rent, transportation spent, and etc. that have to pay in shops that are called the direct parents' non-institutional costs (DPNC) of education (Lugaz \& Grauwe, 2016). In the case of indirect parents' financing (IPF), the student's time spent in an educational institution is also taken into account. Student's time cost could have been utilized in an alternative way is here referred to as IPF (Psacharopoulos \& Woodhall, 1995).

Education funding develops and expands a person's knowledge and skills, increases productivity and improves healthy life through the education(UNESCO, 2015). Parents' funding in education is on the rise, as long-term benefits can be derived from increased individual performance potential in the near future (Weisbrod \& Hansen, 1968). It is believed that education is almost universally financed by taxation. It means the central or local government tends to invest in education. However, the usual pattern is that direct tuition fees are financed by state and other educational expenditures except the tuition fees are financed by parents in higher education(Sheehan, 1973).Likewise, another pattern is that college students especially those with limited financial resources, do not pay tuition fees that have been managed from donations, government grants, scholarships, and etc., however, those students should expend in the DPNC (Paudel, 2019b). The financing aspect of higher education can be realized as in this meaning also that highly trained and educated people are paid more than the uneducated and unskilled (Dolton, 2006), so they have to invest in education. It is also seen that majority of the socialists, educationalists, politicians, economists and capitalists have univocally agreed that higher education provides the higher private benefits so individual person should finance in higher education (Schiefelbein, 1983).

In Nepal, education is classified on the basis financial investment model like governmentbased, community-based and private. In the government-based educational institutions, the government makes spending. The community-based educational institutions are functioning based on financial assistance and grants of community, parents and donor agencies, however, the QAA certified colleges get grants from University Grant Commission (UGC) also. Likewise, only students or their parents incurs the financial burden in the private educational institutions 
(Paudel, 2019b). Nepal government has allocated 9 to 17 percent budget to education sector in different fiscal years, and among it 56 to 63 percent budget has been allocated to pre-primary, primary and secondary level in different fiscal year. Likewise, 17 to 24 percent budget has also been allocated to informal education of that total educational budget(Ministry of Finance, 2078). However, it can be said that government financing in higher education is very low in Nepal. In one hand, Nepal is a least developed country, and on other hand, large number of students are living below poverty line,so, they cannot afford the high cost of higher education. Because, number of absolute poor people is 18.7 percent and number of multi-dimensional poor people is 28.6 percent in Nepal (Ministry of Finance, 2078), but nominal income of poorest 20 percent each people is Rs 15,888.00 annually and poverty line income is Rs 19,262.00 annually (CBS, 2011). However, a question is moved up that how many amount has been invested by the parents as direct private non-institutional cost of education to get the certificate of a master degree from the University Campus having the semester system under the TU.

Nepal has adopted a mixed economy, therefore, not been able to stay away from privatization and commercialization (Paudel, 2019a).Therefore, the government of Nepal has taken the costsharing policy in higher education. It means that investment is of all like government, community, and private sector in higher education of Nepal. Private investment is a major part of financing education. Likewise, on the one hand, private financing in education is directly related to future earnings and on the other hand it affects the current enrollment of higher education. Therefore, it needs to be analyzed.

Similarly, in the context of Tribhuvan University (TU), on the one hand some concerned persons are accusing to the program designers of the master level that they have carried out on the basis of advises of donor agencies without any preparing to implement all these programs that have implemented now, and on the other hand none of the research has yet disclosed the financing amount of higher education to obtain a graduate level under the semester system. Therefore, this study has tried to answer the question of how much amount should be invested as direct private non-institutional costs to gain the master degree under the semester system from the TU of Nepal. The study is expected to help academicians and government officials to formulate educational policies and help parents to decide whether to enroll their children at that level at all.

Thus, it is obvious that the parents' financing as non-institutional cost of education has to be analyzed, however, has not yet done. So, the objective of this study is to analyze the parents' noninstitutional financing of education at a master level under the semester system of TU. Likewise, based on the objective, two research questions have been made in the following forms. The first is 'What is the size of parents' financing as non-institutional cost of education at master level?', and the second is 'Dose the funded amount by the parents in the education differ between the girls and the boys, and between institutions/faculties?' This study therefore has tried to generate conclusions based on aforesaid objective and research questions. But this study has not covered public financing, college, and university-related (institutional) financing. Similarly, no hypotheses have been tested. The data collection procedures are directed by the research questions. 


\section{Method}

The Study following descriptive research design has collected both the qualitative and the quantitative data. The primary data have been collected from participants (students) by using structured and semi-structured questionnaires, by conducting face to face interview. Likewise, secondary data have also been collected from library and e-library's books, articles and different reports. The simple random, stratified and purposive sampling methods have been used in the study. The study has focused on generalization, and the criteria have been made based on the notions of internal/external validity.

Study site of this study is University Campus, Kirtipur, and the study unit are students who are studying at fourth semester under the central departments. There are three faculties like Faculty of Education, Faculty of Humanities and Social Sciences, and Faculty of Management, and one institution like Science and Technology. Likewise, there are 42 central departments under these faculties and institution or this Campus. All students who are studying in master degree at semester system by regular programs under the University Campus has been assumed as population for this study. Faculties are chosen by using the purposive sampling method because there are only three faculties, and only one institution, and likewise, the aim of research is to compare the costs of education in between genders and among departments. Likewise, the Central Department of Education and Management are also chosen by purposive sampling because there is only one central department of education and only one Central Department of Management.

Likewise,Central Department of Nepali and English of 22 central departments from the Faculty of Humanities and Social Sciences,and Central Department of Zoology and Chemistry of 13 central departments from the Institution of Science and Technology are selected by using lottery method of simple random sampling. Similarly, the Head/administrative officers of each selected departments, dean/administrative officers of each selected faculties, account officer of central library and account officer of exam control office are chosen by purposive sampling techniques. Total number of students who are studying in fourth semester, they are 450, 250, 20, 50, 55 and 60 (central departments, 2020) in Central Department of Education, Management, Nepali, English, Zoology and Chemistry respectively. Among them, 20/20 students are selected by using stratified random sampling technique, but census technique had been used to select 20 students from Central Department of Nepali because there are only 20 students.

120 of 885 students ( 60 girls and 60 boys) or 13.56 percent have been participated in the study. Likewise, 6 students (one from each selected department) are taken by purposive sampling to collect qualitative data. The student questionnaires have been pre-tested before research period. Ethical considerations have been fully followed. Respondents (students) and other offices were informed about the purpose of collecting data. When they were convinced and then the data were gathered. The collected data have been analyzed by using descriptive statistics such as average or mean, table, bar- diagrams and pie-chart, and then the results are interpreted.

\section{Result}

The result section of the study incorporates sex-wise and department-wise total and average financing/costs of education at master level. The objective of the study is to analyze the parents' 
financing as non-institutional cost of education at master level. The first research question is 'what is the size of parents' financing as non-institutional cost of education at master level?', and second question is that' Does the funded amount by the parents in the education differ between the boys and the girls, and between institutions/faculties?' The result of the study has been presented being based on the objective and research questions. Similarly, the amount invested by the parents as non-institutional cost for obtaining a master's degree under the semester system has been analyzed by categorizing it into thirteen different parts.

The total expenditure amount is presented in Nepalese currency (NRS) and US dollar (\$) based on the exchange rate of 1:0.0085 provided by Nepal Rastra Bank on December 1, 2020(Nepal Rastra Bank, 2020).The total expenditure is calculated by adding the item wise total amount and the average expenditure is calculated by dividing the total amount by the number of students. In Table 1, the amount within the parenthesis shows in US dollar and outside it is in Nepalese currency (NRS). The data are collected from total 120 students of different six central departments of University Campus- Central Department of Education, Central Department of Nepali, Central Department of English, Central Department of Management, Central Department of Zoology, and Central Department of Chemistry. The findings are shown in Table 1.

Table 1. Items and central department wise total annual costs (2020, In NRS \&US\$).

\begin{tabular}{lcccccc}
\hline Items & Education & Nepali & English & Manage & Zoology & Chemistry \\
Rent & 883500 & 887964 & 1282538 & 1295250 & $1,287,000$ & 1116000 \\
& $(7509.8)$ & $(7547.7)$ & $(10901.6)$ & $(11009.6)$ & $(10939.5)$ & $(9486.0)$ \\
Transport & 71500 & 159236 & 156428 & 129250 & 245,388 & 228800 \\
& $(607.8)$ & $(1353.5)$ & $(1329.6)$ & $(1098.6)$ & $(2085.8)$ & $(1944.8)$ \\
Tour, picnic \& & 94875 & 51590 & 217756 & 140875 & 270556 & 52400 \\
field trip & $(806.4)$ & $(438.5)$ & $(1850.9)$ & $(1197.4)$ & $(2299.7)$ & $(445.4)$ \\
Stationary & 130625 & 171864 & 155095 & 125125 & 279994 & 172800 \\
& $(1110.3)$ & $(1460.8)$ & $(1318.3)$ & $(1063.6)$ & $(2379.9)$ & $(1468.8)$ \\
Uniform with bag & 82375 & 121968 & 83102 & 69812 & 106392 & 112200 \\
& $(700.2)$ & $(1036.7)$ & $(706.4)$ & $(593.4)$ & $(904.3)$ & $(953.7)$ \\
Study instruments & 402000 & 953260 & 134431 & 513625 & 443,300 & 660000 \\
& $(3417.0)$ & $(8102.7)$ & $(1142.7)$ & $(4365.8)$ & $(3768.1)$ & $(5610.0)$ \\
Reading materials & 162500 & 204820 & 223532 & 199750 & 317746 & 226000 \\
& $(1381.3)$ & $(1741.0)$ & $(1900.0)$ & $(1697.9)$ & $(2700.8)$ & $(1921.0)$ \\
Coaching outside & 48250 & 0 & 17776 & 40000 & 188,760 & 40000 \\
the campus & $(410.1)$ & $(0.0)$ & $(151.1)$ & $(340.0)$ & $(1604.5)$ & $(340.0)$ \\
College tiffin & 360250 & 249018 & 298192 & 350625 & 352,352 & 466400 \\
& $(3062.1)$ & $(2116.7)$ & $(2534.6)$ & $(2980.3)$ & $(2995.0)$ & $(3964.4)$ \\
Internet & 107175 & 119196 & 182648 & 109500 & 160,720 & 157200 \\
& $(911.0)$ & $(1013.2)$ & $(1552.5)$ & $(930.8)$ & $(1366.1)$ & $(1336.2)$ \\
Others & 9250 & 0 & 82214 & 113875 & 344630 & 100000 \\
& $(78.6)$ & $(0.0)$ & $(698.8)$ & $(967.9)$ & $(2929.4)$ & $(850.0)$ \\
Total & 2352300 & 2918916 & 2833712 & 3087687 & 3996838 & 3331800 \\
& $(19994.6)$ & $(24810.8)$ & $(24086.6)$ & $(26245.3)$ & $(33973.1)$ & $(28320.3)$ \\
\hline
\end{tabular}

Source: Field survey -2020. 
The different items which are included to measure the parents' non-institutional financingin the education include house rent, hostel, college transportation, educational tour, educational picnic, all types of stationary, text books, reference books, photocopy, printing,study instruments like computer and other devices, college uniform (shirt, pant, tie, shoes, socks, coat, sweater, etc.), college bag,coaching and tuition out of the college, college tiffin,e-mail \& internet,educational donation and field trip. However, all these items are regrouped under eleven items for simplicity that are rent, transport, tour, picnic \& field trip, stationary, uniform with bag, study material with computer, reading materials, coaching outside the campus, college tiffin, internet, and other.

On the basis of this total annual parents' non-institutional financing of education of 120 student, the average costs for each student is calculated by dividing the total costs by the number of students. The average expenditure is presented in Nepalese currency (NRS) and US dollar (\$) based on the exchange rate of 1:0.0085 provided by Nepal Rastra Bank on December 1, 2020(Nepal Rastra Bank, 2020).In Table 2, the amount outside the parenthesis is in Nepali currency (NRS) and the amount inside it is in US dollars (\$). The value of unit cost or average cost of education is presented in Table 2 below.

Table 2:Items and central department wise average cost (2020, In NRS \&US\$).

\begin{tabular}{llllllll}
\hline Items & Education & Nepali & English & Manage & Zoology & Chemistry & $\begin{array}{c}\text { Total } \\
\text { in \% }\end{array}$ \\
Rent & 44175 & 44398 & 64127 & 64763 & 64350 & 55800 & 36.46 \\
Transportation & $(375.5)$ & $(377.4)$ & $(545.1)$ & $(550.5)$ & $(547.0)$ & $(474.3)$ & \\
& $(30.4)$ & $(67.7)$ & 7821 & 6463 & 12269 & 11440 & 5.35 \\
Tour, picnic \& & 4744 & 2580 & 10888 & $(54.9)$ & $(104.3)$ & $(97.2)$ & \\
field trip & $(40.3)$ & $(21.9)$ & $(92.5)$ & $(59.9)$ & $(115.0)$ & $(22.3)$ & 4.47 \\
Stationary & 6531 & 8593 & 7755 & 6256 & 14000 & 8640 & 5.59 \\
& $(55.5)$ & $(73.0)$ & $(65.9)$ & $(53.2)$ & $(119.0)$ & $(73.4)$ & \\
Uniform with bag & 4119 & 6098 & 4155 & 3491 & 5320 & 5610 & 3.11 \\
& $(35.0)$ & $(51.8)$ & $(35.3)$ & $(29.7)$ & $(45.2)$ & $(47.7)$ & \\
Study instruments & 20100 & 47663 & 6722 & 25681 & 22165 & 33000 & 16.77 \\
& $(170.9)$ & $(405.1)$ & $(57.1)$ & $(218.3)$ & $(188.4)$ & $(280.5)$ & \\
Reading materials & 8125 & 10241 & 11177 & 9988 & 15887 & 11300 & 7.20 \\
& $(69.1)$ & $(87.0)$ & $(95.0)$ & $(84.9)$ & $(135.0)$ & $(96.1)$ & \\
Coaching outside & 2413 & 0 & 889 & 2000 & 9438 & 2000 & 1.81 \\
the campus & $(20.5)$ & $(0.0)$ & $(7.6)$ & $(17.0)$ & $(80.2)$ & $(17.0)$ & \\
College tiffin & 18013 & 12451 & 14910 & 17531 & 17618 & 23320 & 11.21 \\
& $(153.1)$ & $(105.8)$ & $(126.7)$ & $(149.0)$ & $(149.7)$ & $(198.2)$ & \\
Internet & 5359 & 5960 & 9132 & 5475 & 8036 & 7860 & 4.52 \\
& $(45.5)$ & $(50.7)$ & $(77.6)$ & $(46.5)$ & $(68.3)$ & $(66.8)$ & \\
Others & 463 & 0 & 4111 & 5694 & 17232 & 5000 & 3.51 \\
& $(3.9)$ & $(0.0)$ & $(34.9)$ & $(48.4)$ & $(146.5)$ & $(42.5)$ & \\
Total & 117615 & 145946 & 141686 & 154384 & 199842 & 166590 & 100.00 \\
& $(999.7)$ & $(1240.5)$ & $(1204.3)$ & $(1312.3)$ & $(1698.7)$ & $(1416.0)$ & \\
Total in \% & 12.70 & 15.76 & 15.30 & 16.67 & 21.58 & 17.99 & \\
\hline
\end{tabular}

Source: Field survey -2020 . 
The Table 1 and Table 2 have shown that the annual average direct private non-institutional cost varies by departments. Likewise, this cost also varies by items. It is found that each student spends 36.46 percent of the total expenditure on rent which is the highest as compared to other items.

It is seen on the study site that the students have spent a huge amount on the rent which is 36.46 percent of the total expenditure.

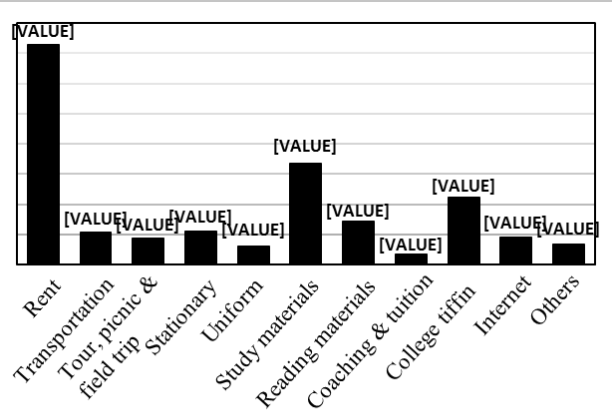

Figure 1: Non-institutional financing in higher education Source: Table 1 and Table 2. Similarly, in the second position, students have spent on study material which is 16.77 percent of the total expenditure. Similarly, college tiffin and reading materials are seen in the third and fourth places and the amount spent on these items are 11.21 percent and 7.20 percent respectively. Expenditure on stationery, transportation, internet, tours, picnics and field trips, and college uniforms are approximately the same, with 5.59 percent, 5.35 percent, 4.52 percent, 4.47 percent, and 3.11 percent respectively. The lowest amount has been spent on college off-time coaching and tuition which is 1.81 percent of the total expenditure. Similarly, 3.51 percent of the total expenditure is on other items like educational donations and grants, reception of guests or parents on the occasion of convocation, attending the convocation, taking and printing of photographs, photocopying, lamination, and stitching of certificates, etc.

Similarly, on an average, each student, except Nepali subject students, pays 1.81 percent of the total expenditure on off-campus group coaching and individual tuition which is the lowest as compared to other items. The students who studying their level of education is same like master degree, however, their disciplines are different like master degree on education which is related to teaching profession in the future, master degree on Nepali discipline which is related to Nepali language and literature, and master degree on English discipline which is related to English language and literature. It means that their level of degree and studying campus is same, however, study contents and future professions are different according to discipline. The department wise this type of cost can be explained with the help of figure.

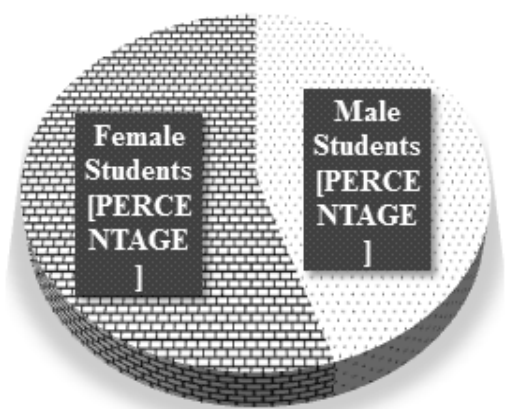

Figure 2: Financing on non-institutional items of education.

Source: Table 1 and Table 2.

The parents' financing on the non-institutional items of educations of these various six disciplines differ from each other. On an average, the students of education discipline have spent 12.70 percent of the total expenditure which is minimum amount as compared to the students of other disciplines. It means that students of education discipline spend less amount as compared to students of other disciplines. Similarly, students of other disciplines like Nepali, English, 
Management, Zoology and Chemistry spent 15.76 percent, 15.30 percent, 16.67 percent, 21.58 percent and 17.99 percent respectively. Of these, the cost of zoology students is 21.58 percent which is more than the students of other disciplines.

The direct private non-institutional costs of these various six subjects can be presented by gender. This type of cost varies by genders like male and female. The total sample size is 120 students, and among them, 20 students from each department are analyzed. Similarly, 50 percent of the students are male and 50 percent

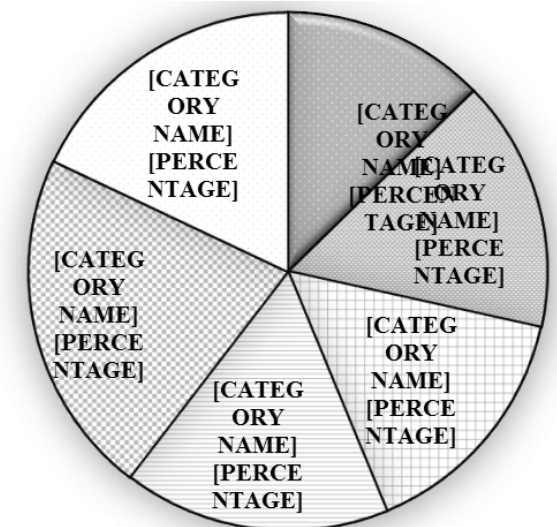

Figure 1: Parents' financing on noninstitutional items of education.

Source: Table 1 and Table 2. are female. It has been found that the cost of the female students is higher than the male students. On average, the female students have spent 55 percent of the total expenditure, and the male students have spent only 45 percent of the total expenditure. This means the female students spent 10 percent more than the male students.

\section{Discussion}

The data on direct private non-institutional cost of education has been collected by evaluating twenty five items, and subsequently, these items are reduced to eleven items. The aggregated data is presented in Nepalese currency (NRS) and US Dollar (\$) based on exchange rate of 1:0.0085 provided by Nepal Rastra Bank on December 1, 2020. The funding on these items indicates that the cost of education is spent by the students or their parents beyond the accounts section of the respective central departments. These data have been collected from respondents such as students which are directly related to the expenditure on the shops. This means that students pay cash to purchase various items and receive slips or bills from the respective shops.

It is measured in the sampled campus that direct private financing has been found different according to each central department. In the sampled campus, it is found that each students of Education Discipline have financed NRS 117615.00 (\$999.73) annually as direct private noninstitutional costs to achieve the master degree. Likewise, each students of Nepali Discipline, English Discipline, Management Discipline, Zoology Discipline and Chemistry Discipline have annually funded NRS 145945.80 (\$1240.54), NRS 141685.60 (\$1204.33), NRS 154384.35 (\$1312.27), NRS 199841.90 (\$1698.66), NRS 166590.00 (\$1416.02) and NRS 926062.65 (\$7871.53) respectively as direct private non-institutional costs to achieve the master degree from the respective departments. It can be said that among the Central Departments run under the University Campus, Kirtipur of Tribhuvan University of Nepal, the most expensive students are from Zoology Central Department, and the least expensive students are from Central Department of Education.

Rent is a major part of the direct private non-institutional cost of education. Theoretically, rent is the price paid for the use of land and other free gifts of nature, but according to modern 
economists, rent is the surplus earnings of factors over their transfer income. In the study, rent is defined as the price paid by the renter to the owner of the house on account of the use of room or house or flat. It is found that out of sample students in Kathmandu Valley, only 1.67 percent students live in their own homes, but 98.33 percent students do not have their own house and live in rented houses. It is further found that on an average, monthly, each student has to pay NRS 4,689.04 (\$39.86) to the owner of the house in Kathmandu, especially in Kirtipur.The rent is the major part which have covered the 36.46 percent of total expenditure. On the basis of this data, it can be said that rent is high as compared to other sector of funding. Similarly, transportation cost is also an important part of the study. In the study site, 63.42 percent students use public vehicles, 2.39 percent use private vehicles and 34.19 percent students do not use any vehicles. In the study area, it is also found that on an average, every day,each student spends NRS $37.52(\$ 0.32)$ in transportation. Likewise, transportation has covered the 5.35 percent of total expenditure.

Educational tour, visit, picnic and field trip are organized by each Central Departments as an academic program. These programs are based on nature of curriculum, teaching techniques and strategies, resource excess condition of institution or students, suitable season, appropriate issue and area, type of research, and policy of education. But, it is most usefulness to the students in learning. In the study site, it is found that on an average, annually one student has spent NRS 2,942.67 (\$25.01) for educational tour,NRS 1,646.84 (\$14.0) for picnic, and NRS 2,310.34 (\$19.64) for field trip. As a whole, this sector of funding has covered the 4.47 percent of total expenditure. The pen, pencil, copy, ink, diary, color, geometric box, calculator, eraser, highlighter, stapler, file, punching, gum, tape, scissor, sticker, white paper, drawing paper, pin, scale, cutter, envelop, refill, map, globe, exam board, purse/pocket box, photocopy, printing, and, etc. are the necessary items of the stationary. It is found that each student has spent an average of NRS 8629.19 (\$73.75) annually on these items.

Uniform is a logo for particular college, and it shows the manner and discipline of students, as well as reduces race, class and religious inequalities between students which have made by the society (Horvat \& Antonio, 1999). However, the sampled campus has not determined formal uniform for students. It is observed that in students' own choice, approximately all male students wear shirts, t-shirts, pants, jackets, and shoes, and likewise, approximately all female students wear shirts, t-shirts, pants, tops, kurtas, salwar, sandals, and etc. Similarly, students carry the bag as they wish. It is found that in sampled campus, each students has spent an average of NRS $2,655.5$ (\$22.57) annually on these items. On the basis of this data, it can be said that it is not a sufficient amount. Likewise, the computer, laptop, mobile, table, chair, and etc. are the study instruments. It is observed that 61.2 percent of students do not have a personal computer and laptop, 66.8 percent of students do not have a chair and table in their study room, but all students have a mobile of their own. It is found that the per-student funded amount in these items is NRS 25888.47 (\$220.05) for a year which is the 16.77 percent of total expenditure.

The next one important part is the reading materials. A question was asked to the students, 'Have you purchased reading material like textbooks, reference books, other printing materials, newspapers, magazines, research reports, journal articles, publications of the government and non-governmental organizations, international publications, etc.? If yes, how much have you 
spent on these items in a year? In response to this question, everyone agreed to buy textbooks, only 28.9 percent of students agreed to buy reference books as well, and all said that 'we study other material from the library, not from the purchase'. It is found that the per-student funded amount in these items is NRS 11119.57 (\$94.52) for a year which is the 7.2 percent of total expenditure. Private coaching and tuition refers to supplementation of tutoring, covering subjects that are already covered in the school and tutoring provided by entrepreneurs and individuals for profit-making purpose(Bray, 1999). It always gives much emphasis on privatization of education. Students go to colleges in its time as well as also go to private tuition institutions in other time. These types of institutions help sometime positively and hamper sometime negatively to the students and educational system. In the study site, it is seen that besides the students of central department of Nepali, other students go to private institutions for coaching and tuition. For this, on an average, one student has to fund NRS 2789.88 (\$23.71) in a year and this amount has occupied the 1.81 percent share of total expenditure.

College tiffin refers to the daily expenses of the students. It is divided into three categories like canteen-made, home-made and fast-food. It is found that students have not bagged tiffin from their homes. Majority of the students, for example, 85.6 percent take canteen-made tiffin and only 14.6 percent students take fast-food like noodles, biscuits, etc. In the study site, it is measured that on an average, a student has spent NRS 17306.98 (\$147.11) annually, and NRS 96.15 (\$0.82) every day as tiffin cost, and this amount has occupied 11.21 percent share of total expenditure. The internet cost is a part of educational cost. It is a network of networks that consists of millions of private, public, academic, business, and government networks, of local to global scope, that are linked by a broad array of electronic and optical networking technologies. In the present days, all students use the internet as a teaching-learning material. In the study site, on an average, each student has invested NRS 6970.33 (\$59.25) annually, and NRS 580.86 (\$4.94) monthly. The internet cost has occupied the 4.52 percent share of total expenditure.

The educational donations and grants, reception of guests or parents on the occasion of convocation, attending the convocation, taking and printing of photographs, photocopying, lamination, and stitching of certificates, etc. have been included in the title of other costs of education. Donation is not a compulsory funding, however, academic institutions request to the students, other individuals, and government and non-government institutions. With reference to it, researcher query is that have students donated some amount of money to their institution where they are studying or not? From the research, it is seen that few students have given some amount of money to the respective departments in cash and things (textbooks, reference books, furnishers, equipment, and etc.) as donation. In the sampled campus, it is seen that on an average, each student has spent NRS 5416.41 (\$46.04) annually for these items, and this amount is the 3.51 percent of total expenditure.

\section{Conclusions}

The education is assumed as an agent of change because it in a broader sense improves capacity of the individuals and institutions, and it makes close relation with economic, social, cultural and demographic changes as a national development. Thus, educational expenditure has been increasing over the years around the world. Currently education is basically guided by economic system. Because, who have sufficient money like politician, job-holders, business man they 
easily invest and get education and vice-versa. It means that in the current world like Nepal the higher education is in holding of economically successors. It is measured in the sampled campus that direct private financing has been found different according to each central department.

Based on results and discussion, it is concluded that to live in Kathmandu as a student of University Campus, of Tribhuvan University, annually each student should manage the direct private non-institutional costs NRS 1,17,615.00 (\$999.73), NRS 1,45,945.80 (\$1,240.54), NRS 1,41,685.60 (\$1,204.33), NRS 1,54,384.35 (\$1,312.27), NRS 1,99,841.90 (\$1,698.66), NRS 1,66,590.00 $(\$ 1,416.02)$ and NRS 9,26,062.65 $(\$ 7,871.53)$ to get the master degree from the Central Department of Education, Nepali, English, Management, Zoology and Chemistry respectively. In addition, the students should expend NRS 56,268.77 (\$478.28) annually in rent which is highest by 36.46 percent of total expenditure. The lowest amount has been spent on college off-time coaching and tuition which is 1.81 percent of the total expenditure. Likewise, comparing the male and female students, the female students are more expensive than male students. The female students have expended NRS 1,69,993.44 $(\$ 1,444.94)$ or 55.0and the male students have expended percent NRS $1,38,693.84(\$ 1,178.9)$ or 45.0 percent, andthe female student's amount is higher by NRS $31,299.60$ (\$266.05) or 22.57 percent.

\section{References}

Aghenta, J. A. (1993). Principles and practices of educational planning: Focus on the developing countries. Benin: Nigerian Society for Educational planning (NSEP).

Akpotu, N. E. (2008). Social Cost Analysis of Secondary Education in South West Nigeria (1996-2001). Journal of Social Sciences, 16(1), 27-33. doi:10.1080/09718923.2008. 11892598.

Bray, M. (1999). The private costs of public schooling: Household and community financing of primary education in Cambodia. Paris: International Institute for Educational Planning, UNESCO.

CBS. (2011). Nepal Living Standards Survey-2010/11. Kathmandu: Central Bureau of Statistics, National Planning Commission Secretariat, Government of Nepal.

Chattopadhyay, S. (2007). Exploring alternative sources of financing higher education. Economic and Political Weekly, 1(1), 4251-4259. Retrieved from https://www.academia. edu/1320707/Exploring_Alternative_Sources_of_Financing_Higher_Education.

Dolton, P. J. (2006). Teacher supply. In E. Hanushek \& F. Welch (Eds.), Hand Books of the Economics of Education. (Vol. 2, pp. 1079-1161). doi:10.1016/s1574-0692(06)02019.

Horvat, E. M., \& Antonio, A. L. (1999). Hey, those shoes are out of uniform: African American girls in an elite high school and the importance of habit us. Anthropology \& Education Quarterly, 30(3), 317-342. Retrieved from https://anthrosource.onlinelibrary.wiley. com/doi/pdf/10.1525/aeq.1999.30.3.317.

Jamison, D. T. (2009). Cost effectiveness analysis: concepts and applications. In R. Detels, J. McEwen, R. Beaglehole, \& H. Tanaka (Eds.), Method of Public Health (5th ed., Vol. 2, pp. 767-782). London: Oxford University Press. Retrieved from http://depts. washington.edu/cfar/sites/default/files/uploads/core-program/user 164/Jamison\%20 CEA\%20Concepts\%20and\%20Applications.pdf. 
Khandagale, V. S., \& Pandya, S. R. (2014). Private cost of education and academic achievement of students: An analysis by school types. IOSR Journal of Humanities and Social Science, 19(2), 39-43. doi:10.9790/0837-19223943

Lugaz, C., \& Grauwe, A. D. (2016). Improving school financing: The use and usefulness of school grants (Lessons from East Asia and the Pacific). In. Paris: International Institute for Educational Planning, United Nations Educational, Scientific, and CulturalOrganization (UNESCO). Retrieved from https://unesdoc.unesco. org/ark:/48223/pf0000246372? 10=null\&queryId=b9c85823-f3d1-408e-87c2$7 \mathrm{a} 59 \mathrm{~b} 00 \mathrm{dba} 14$.

Ministry of Finance. (2078). Economic survey - 2020/21. Kathmandu: Author. Retrieved from https://www.mof.gov.np/uploads/document/file/1633341980_Economic\%20 Survey\%20(Engslish)\%202020-21.pdf.

Nepal Rastra Bank. (2020). Foreign exchange rate for december 1, 2020. Retrieved from https:// www.nrb.org.np/forex/.

Obradovic, S. (2008). Education and economic growth. OALib Journal, 6(10), 197-206. doi:http://lexetscientia.univnt.ro/download/215_lesij_es_XV_2_2008_art_16.pdf.

Paudel, M. R. (2019a). Analysis of direct private investment: The case of bachelor's level in community college. Education and Development, 29(1), 103-118. Retrieved from https://doi.org/10.3126/ed.v29i0.32575.

Paudel, M. R. (2019b). A comparative analysis of institutional and non-institutional direct private cost in higher education of nepal. Interdisciplinary Research in Education, 4(1), 53-66. doi:https://doi.org/10.3126/ire.v4i1.25710.

Psacharopoulos, G., \& Woodhall, M. (1995). Education for development: An analysis of investment choices. Washington DC: World Bank, printed by Oxford University press.

Schiefelbein, E. (1983). Educational financing in developing countries: Research findings and contemporary issues. Canada: International Development Research Centre. Retrieved from https://idl-bnc-idrc.dspacedirect.org/bitstream/handle/10625/6198/IDL-6198.pdf.

Sheehan, J. (1973). The Economics of education. London: George Allen \& Unwin Ltd.

UNESCO. (2015). Financing of secondaryeducation in the Asia-Pacific Region. (Education policy research series discussion document no. 4). Bangkok: Education Policy and Reform Unit, UNESCO. Retrieved from https://www.researchgate.net/publication/276271715 Financing_Secondary_Education_in_Asia_and_Pacific.

UNESCO \& OECD. (2002). Financing education - investments and returns (analysis of the world education indicators - 2002 edition; executive summary). France: UNESCO Institute for Statistics \& Organisation for Economic Co-Operation and Development. Retrieved from https://www.oecd.org/education/skills-beyond-school/2494749.pdf

Weisbrod, B. A., \& Hansen, W. L. (1968). An income-net worth approach to measuring economic welfare. The American Economic Review, 58(5), 1315-1329. Retrieved from https:// papers.ssrn.com/sol3/papers.cfm?abstract_id $=1856618$. 